\title{
EXPORTS AND THE GRAVITATIONAL MODEL- THE BRAZILIAN CASE AND THE MERCOSUL, NAFTA AND EU BLOCKS
}

\author{
MARIA CLARA PINTO RIBEIRO \\ CEOS.PP/Área de Economía/ISCAP/IPP, PORTUGAL. \\ $E$-mail: mclara@iscap.ipp.pt \\ FRANCISCO VITORINO DA SILVA MARTINS \\ Departamento de Ciências Empresariais/Faculdade de Economia da Universidade do Porto, PORTUGAL \\ E-mail:diamar@netcabo.pt \\ RAQUEL DA COSTA PEREIRA \\ CEOS.PP/Área de Economía/ISCAP/IPP, PORTUGAL \\ $E$-mail: rpereira@iscap.ipp.pt \\ JOSÉ ROBERTO DA SILVA \\ IFMG- MINAS GERAIS/ISCAP/IPP, Brasil, PORTUGAL \\ E-mail: joseroberto@iftm.edu.br
}

\section{ABSTRACT}

Exports are part of the foundation of the economy's dynamics in Brazil. The objective is to study the behaviour of aggregate Brazilian exports from 2000-2016 for the countries that belong to economic blocks: MERCOSUL, NAFTA and EU. Four econometric models were built (OLS/random effects), in order to estimate the behaviour of Brazilian exports. The economy's dimension and the existence of a maritime border potentiate Brazilian exports but the common language has no influence on exports.. A non-expected conclusion is the higher attractiveness of EU and NAFTA blocks compared to the MERCOSUL. Distance, post-2008 crisis and isolation of small insular economies dissuade exports.

Key-words: Brazilian Exports; Economic blocks; Gravitational Models; Panel Data

Las exportaciones y el modelo gravitacional: El caso brasileño y los bloques mercosur, nafta y ue

\section{RESUMEN}

La economía de Brasil se basa en la dinámica de sus exportaciones. El objetivo es estudiar el comportamiento de las exportaciones agregadas del 2000-2016 para los países que pertenecen a bloques económicos: MERCOSUR, NAFTA y UE. Cuatro modelos econométricos fueron construidos (OLS / efectos aleatorios) con el fin de estimar el comportamiento de las mismas. Dichas exportaciones son potenciadas por la dimensión de la economía, la existencia de una frontera marítima con los países de destino, pero la lengua común no influye en las exportaciones. Una conclusión inesperada es el incremento del atractivo de los bloques de la UE y el TLCAN en comparación con el MERCOSUR. La distancia, la crisis posterior al 2008 y el aislamiento de las pequeñas economías insulares disuaden a las exportaciones.

Palabras clave: Exportaciones Brasileñas; Bloques económicos; Modelos Gravitacionales; Datos en Panel.

JEL F14, F15

Artículo recibido el 4 de febrero de 2019 y aceptado el 27 de mayo de 2019 Artículo disponible en versión electrónica en la página www.revista-eea.net ISSN 1697-5731 (online) - ISSN $1133-3197$ (print) 


\section{INTRODUCTION}

The study of the specificities of international trade can be done in light of multiple theoretical frameworks. One of the analytical instruments that has presented itself as being more robust, due to its explanatory power and the relative simplicity of structuring, is the one brought by the gravitational model, primarily imported from the area of knowledge of physics and mechanics (Tinbergen, 1962; Poyhonen, 1963).

Brazil, in the beginning of the present century, presented characteristics that were typical of a worldwide power (alongside China, Russia and India - BRIC countries), with low budget deficit, an administrable inflation rate and, above all else, an export dynamic that generated a positive trade balance (Colin, 2015). Although this virtuous cycle has come down throughout the past years (mainly since 2008 and with a specific emphasis on 2015 and 2016) - a situation that is partially explained by the fact that the logic of Brazilian exports has been based, since the 90s of the XX century, on the reprimatization of the industry, with an orientation towards raw materials - exports are a foundation stone for the Brazilian economy's dynamic.

In the present analysis, we aim to study the behaviour of the aggregated Brazilian exports in the period from 2000 to 2016 for the countries belonging to three economic blocks: MERCOSUL, NAFTA and the European Union (EU). We consider these three blocks because of the fact that the importance of Brazil's trade partners originates, traditionally, in these areas (although China has grown exponentially in the past few years, already being Brazil's main trade partner). Brazil's trade relationships with these three economic blocks - using as endogenous variable the Brazilian exports for the countries belonging to those three blocks in the mentioned period - aim to be explained through economic, demographic and geographic variables, of the origin and the destination countries, using a gravitational model and panel data. In the gravitational model, export attractiveness variables are included (production, economic blocks, maritime access, common language), as well as resistance or limitative variables (distance, geographical isolation, economic and financial crisis).

Four econometric models were built to estimate the behaviour of Brazilian exports, whose differences are related to the estimation method (Method of Least Squares or Method of Random Effects) and with the variables translating the dimension of the measured economies (in absolute values or per capita values).

We show that the economic dimension of the exporting countries and its trade partners are foundational variables to explain Brazilian exports. In the present case, participating in an economic block does not potentiate exports. Distance, the post-2008 crisis and the isolation of small insular economies are dissuading factors for Brazilian exports. The existence of a maritime border and common language in the destination countries seem to potentiate Brazilian exports.

The structure of this paper is as follows: in Section 2, a revision of the literature is presented; in Section 3, the data, methodology and research hypotheses are described; in Section 4, the results are shown and analysed; finally, in Section 5, the conclusions are presented.

\section{LITERATURE REVIEW}

The initial specifications of the gravitational model were imported from the area of knowledge of physics and mechanics and were based on Newton's law of universal gravitation. The gravitational model describes one of the most stable, robust and simple relationships in international economics: the direct interaction between the size of economies and their bilateral trade, on the one hand, and the less attractiveness of trade relations between countries or areas that are more distant, on the other hand (Feenstra, 2004; Bergeijk and Brakman, 2014). The ambiguity of the size of the economies and the distance between countries has allowed the incorporation of additional explanatory variables such as tariff and non-tariff barriers, cultural barriers (language, religion, colonial ties), technological differences, and institutional specificities, enriching the formulation of the original models.

The pioneering formulations of the gravitational model applied to international trade were advanced by Tinbergen (1962), Poyhonen (1963), Linnemann (1966), Aitken (1973), and Sapir (1981) who assumed a specification where bilateral trade flow between two regions is explained by the nominal 
Gross Domestic Product (GDP) of the two regions, by the distance between the two regions and whether or not they belong to the same integrated area (McCallum, 1995).

The application of the gravitational model to international trade developed for three reasons: deepening of the theoretical framework from the 1980s, empirical robustness and the political relevance of the analysis of free trade agreements between countries (Baier and Bergstrand, 2014).

Indeed, one criticism to the application of the gravitational model was the lack of an apparent link to the theoretical support of international trade. However, works developed from the second half of the eighties came forward with the theoretical support of the empirical relationship presented in the gravitational model. Thus, Helpman (1987) presents a first effort to link the theory of market analysis in imperfect competition, incorporating product differentiation into the gravitational model. In the same direction go the works of Anderson (1979), Bergstrand (1985), Helpman and Krugman (1985) and Anderson and van Wincoop (2003) - namely with the connection between the gravitational model and a Helpman-Krugman-Markusen model, considering the existence of intra-industry trade. Deardorff (1998) links the Heckscher-Ohlin-Samuelson (inter-industry trade) model, under conditions of perfect competition, to the gravitational model.

Although the theoretical support of the gravitational model is being constructed, some weaknesses are pointed out. Eaton and Kortum (2002), Anderson and van Wincoop (2003) and Feenstra (2004) suggest that the traditional gravitational model is probably poorly specified due to the omission of multilateral resistance measures, that is, bilateral trade flows are influenced by prices of products in the other $\mathrm{N}-2$ regions, which, in turn, are influenced by the bilateral distance from the $\mathrm{i}$ and $\mathrm{j}$ zones regarding the $\mathrm{N}-2$ regions (Baier and Bergstrand, 2014).

One of the most important political applications of the gravitational model is the computation of gains or losses with the integration processes. The creation and diversion of trade, the foundation stones in the economic analysis of integration, are not easily incorporated and described by the traditional gravitational model, so Bikker (2014) derives a reformulation and generalization of the gravitational model (the Extended Gravity Model ${ }^{10}$ ).

The empirical robustness of the gravitational model, coupled with its somewhat vague and ambiguous formulation (Bergeijk and Brakman, 2014), extended its application to areas other than international trade - notably migratory flows (Helliwell, 1997), direct investments (Egger and Pfaffermayr, 2004), impact of EEC and EFTA (Aitken, 1973).

Numerous empirical studies have been advanced around the gravitational model. Piani and Kume (2000) evaluated the evolution of bilateral flows of international trade and the effects of preferential trade agreements for six economic blocks between 1986 and 1997. For a period of twelve years, data was first grouped in a single block. They were then divided into four periods and, finally, the application of the model for each sample year. In the first application, a single combined regression was estimated. The second one sought to examine the evolution of the effects of the oldest and most recent blocks, created from the beginning of the 1990s. In the third approach, the evolution was evaluated year by year. The authors concluded that, regardless of the blocks being composed of developing countries or not, the Preferential Trade Agreements used in the model were relevant to the creation of an additional trade between the member countries of these economic blocks.

Sá Porto (2002) concluded that the most significant impacts of MERCOSUL occurred in the South and Southeast regions, while the other regions had fewer benefits. According to him, the results suggest that MERCOSUL has contributed to the aggravation of regional disparities in Brazil.

Azevedo (2004), analysing the effects of MERCOSUL on the creation, diversion and suppression of trade, concluded that the formation of the economic block does not in itself change intra-block trade.

To estimate the bilateral trade of MERCOSUL member countries, Gräf and Azevedo (2013) used the gravitational model with panel data, covering a period of 11 years (1999 to 2009) and a bilateral trade flow of 67 countries. This sample accounted for $92.2 \%$ of world imports. In that study, a significant

\footnotetext{
${ }^{10}$ For further developments, see Bergeijk and Brakman (2014), pp. 137-141
} 
approximation was observed between potential trade and effective trade between the block at the end of the period worked, only $3.47 \%$ of potential trade surplus, using the random effects method. However, there were still unexploited opportunities in the case of potential above-the-trade trade, especially between Argentina and Brazil with the smallest partners in the block.

Papazoglou (2007) used a gravitational model using the ordinary least squares method (OLS) and panel data to study the potential flow of international trade in Greece for the years 1993, 1998 and 2003. The sample includes the flows of exports from 14 European Union (EU) member countries out of a total of 26 countries over the period 1993 to 2003. As for Greek imports, they showed little difference between their actual and potential trade for 1993 and 1998. However, for 2003, actual imports surpassed the potential and were justified by the result of the high investment in infrastructures that took place that year in preparation for the country to host the 2004 Olympic Games. With regards to exports, there was a much higher potential for trade, which was attributed to the scarcity of supply of medium and high technology products, highlighting a competitive deficiency of the country.

Tartas (2016) sought to estimate Brazil's potential trade with its main trading partners through econometric approaches based on bilateral trade flows. A sample consisting of more than $80 \%$ of world trade was used in the study, considering 68 countries between 2001 and 2014. According to the results, effective trade in 2014 was significantly higher than the potential, but with few countries (China, India and Argentina), and much lower with other countries of great economic visibility worldwide (Germany, Japan, the United States and France), where potential trade for the same year was above what was actually achieved. Arevalo, Andrade and Silva (2017) analysed coffee exports from Brazil, Colombia and Peru (2000-2013), choosing geographic distance, prices and ease of doing business as common determinants for the three exporters.

Based on the literature, this study intends to answer the question of whether the construction of economic blocks always increases international trade and, more specifically, if in the Brazilian case, the behaviour of its exports is associated with the integration in economic blocks.

\section{DATA, METHODOLOGY AND RESEARCH HYPOTHESES}

\subsection{Data}

A database obtained from the United Nations COMTRADE (2017), the IMF - International Monetary Fund (2017) and the MDIC - Ministério de Desenvolvimento, Indústria e Comércio Exterior (2017) and CEPII - Centre D'Études Prospectives et d'Informations Internationales was built.

The sample corresponds to the period between 2000 and 2016 (17-year period), for the countries belonging to the EU, NAFTA and MERCOSUL, on a total of 35 countries, i.e., a total of 594 observations.

Although imports are the most commonly used variable to observe the bilateral flux of trade (Azevedo, 2004; Dal Pizol, 2010), due to the stronger custom control, for this study the dependent variable to be used in the gravitational equation were Brazilian exports.

In the case of the period in analysis from 2000 to 2016, the correlation between to the total of Brazilian exports and its total imports is 0,972246 (i.e., $94,5 \%$ of exports are associated to imports), so it seems legitimate to adopt exports as the variable to be explained.

Therefore, the variables to be explained are:

EXPORT $\equiv$ Brazil's annual exports for each country (in USD)

EXPORTPC $\equiv$ Brazilian per capita exports (millions of USD per capita)

In the proposed models, the following explanatory variables were used:

PIBBRASIL $\equiv$ Annual GDP of Brazil (in thousand million USD)

PIBPCBRASIL $\equiv$ GDP per capita of Brazil (in USD per capita)

$\mathrm{PIBj} \equiv$ Annual GDP of country $\mathrm{j}$ (in thousand million USD)

PIBPC $\mathrm{j} \equiv$ GDP per capita of country $\mathrm{j}$ (in USD per capita)

DISTBRASILij $\equiv$ Linear distance between Brazil's capital and every other country's capital (in km)

Dummy variables: 
DUNIAOECO = "NAFTA" $\equiv$ Dummy variable that aims to capture the effect on Brazilian exports of the fact that a country belongs to NAFTA instead of MERCOSUL

DUNIAOECO= "UE" $\equiv$ Dummy variable that aims to capture the effect on Brazilian exports of the fact that a country belongs to the EU instead of MERCOSUL

DIDIOMAPT $\equiv$ Dummy variable that codifies the existence of the same idiom as Brazil (Portuguese)

DILHASPEQ $\equiv$ Dummy variable that codifies the two small islands of Cyprus and Malta

TCRISE $\equiv$ Dummy variable that aims to capture the post-crisis effect of 2008

In Table 1, we can see the descriptive statistics of the variables.

Table 1

Variables and descriptive statistics

\begin{tabular}{|l|c|c|c|c|c|c|}
\hline & Mean & Median & Max & Min & SD & Observ. \\
\hline EXPORT & $2.27 \mathrm{E}+09$ & $3.63 \mathrm{E}+08$ & $2.74 \mathrm{E}+10$ & 864199.0 & $4.51 \mathrm{E}+09$ & 595 \\
\hline EXPORTPC & 91.93063 & 42.86049 & 1031.471 & 0.362827 & 141.7712 & 595 \\
\hline PIBBRASIL & 1501.697 & 1669.204 & 2614.027 & 509.7980 & 746.8753 & 595 \\
\hline PIBPCBRAIL & 7706.300 & 8625.130 & 13242.69 & 2859.406 & 3591.387 & 595 \\
\hline PIBJ & 930.3688 & 209.6640 & 18624.45 & 4.059000 & 2473.966 & 595 \\
\hline PIBPCJ & 26261.56 & 21625.48 & 120799.4 & 1153.255 & 20322.17 & 595 \\
\hline DISTBRASILIJ & 8425.006 & 9292.304 & 10623.64 & 1463.434 & 2382.697 & 595 \\
\hline
\end{tabular}

Source: Authors' own elaboration, based on COMTRADE (2017), IMF (2017), MDIC (2017) and CEPII (2017). EVIEWS, version 9.5

\subsection{Methodology}

The initial gravitational model that was used as a basis for the present study is drawn in the equation below, aiming to explain the behaviour of annual Brazilian exports for each country and block, as explained in 3.1.

$$
\begin{aligned}
\ln \text { EXPORT }= & \beta_{0}+\beta_{1} \ln \text { PIBBRASIL }+\beta_{2} \ln \text { PIB }_{j}+\beta_{3} \ln \text { DISTBRASIL } L_{i j}+\beta_{3} \text { DUNIAOECO } \\
& =\mathrm{NAFTA}+\beta_{5} \text { DUNIAOECO } \\
& =\mathrm{UE}+\beta_{6} \text { DIDIOMAPT }+\beta_{7} \text { DILHASPEQ }+\beta_{8} \text { DMAR }+\beta_{9} \text { TCRISE }+\varepsilon_{t}
\end{aligned}
$$

Where $\beta$ represents the parameters to be estimated and $\varepsilon_{t}$ represents the sample error in period t.

Since explanatory variables that are invariant throughout the time (distance) and others that are invariant regarding countries (Brazil's GDP) are present, we cannot consider additional dummy variables due to multi-collinearity, meaning that these specific effects (both sectional and temporal) are already being considered in these invariant variables. Thus the starting estimation method of ordinary least squares (OLS) for panel data.

The alternative estimation method of random effects was also used (cross-section, random effects). Regarding the method of least squares (with panel data) we suggest the estimation alternative with random effects that, facing certain assumptions, may be an interesting estimator for the study. Therefore, we can analyse the robustness of the analysis through different estimation methods.

Due to the fact that sectional effects (for the countries) represent certain invariant characteristics in time, the estimation with random effects of the model is consistent and efficient, but only in the case in which we can admit that the referred individual sectional effects and the explanatory variables are not correlated. The good properties of the estimators are the reason why we present the estimation with random sectional effects (however, the assumption in which they are based cannot be guaranteed).

\subsection{Research hypotheses}

The research hypotheses that we aim to clarify are the following: 
H1: Belonging to an economic block potentiates intra-block trade

$\mathrm{H} 2$ : The largest productive and consumption potentials, measured by GDP, increase international trade

H3: The largest transportation costs, measured by the proxy linear distance between capitals, decrease international trade

H4: The existence of a maritime border increases international trade

H5: The location on a small island does not favour international trade

H6: Sharing the same language favours international trade

H7: The 2008 crisis affected the level of international trade.

Therefore, the introduction of the dummy variable of intra-block trade aims to point to privileged trade between the countries that participate in that same economic block, which is MERCOSUL in the case of Brazil. This study's option privileges the comparison with the countries that belong to other blocks (NAFTA and European Union) regarding those that belong to MERCOSUL. It depends on the attractiveness of the MERCOSUL block when compared to the other blocks; therefore, it is expected that the coefficient sign is positive (bigger relative attractiveness of the MERCOSUL) - H1.

The supply and demand of the participating countries, reflected by the GDP of the exporting country (productive potential), as well as the GDP of the importing country (consumption potential) may be catalysers of international trade. Therefore, the highest the GDP of both countries, the highest tends to be the volume of bilateral trade. It is expected that the index is positive for these variables of the model $-\mathrm{H} 2$.

Regarding the distance between the two countries, the higher it is, the higher the transportation costs, implying a further onus on the prices of imported products, which leads to the natural tendency to keep trade with closer countries, especially the ones at the borders. A negative coefficient for the distance variable is expected, precisely due to the fact that trade is inversely proportional to its increase $-\mathrm{H} 3$.

The expected value for the coefficient of the dummy variable MAR has a positive sign, as trade becomes easier with countries that possess port areas than with other countries - H4.

The dummy variable ILHASPEQ aims to detect territorial isolation as an influence for trade relationships, being expected a negative value for the coefficient, justified by the difficulty that such an isolation represents for bilateral trade. In this case, the islands Cyprus and Malta are codified (small islands) $-\mathrm{H} 5$.

The dummy variable IDOMAPT is justified by the possible ease in negotiations. In the case of this study, it is expected a low significance of this variable for trade, as the only country to receive the value 1 in this dummy will be Portugal. A positive value for the coefficient is expected - H6.

Finally, the expected sign for the dummy variable TCRISE is negative, capturing the effect of the 2008 crisis (post-crisis period) in the economic dynamics of Brazil, measured by its exports $-\mathrm{H} 7$.

The used software was EViews, version 9.5.

\section{RESULTS}

In this section, we will present the suggested models and the results of the estimations.

Four models were suggested. In models 1 and 3, we used the least squares method (OLS), panel data, while for models 2 and 4 we applied the alternative estimation method of random effects (cross-section random effects). For models 1 and 2, we assume the variables exports and GDP in absolute values, while in models 3 and 4 those variables are considered per capita, adjusted for the size of the countries.

Model 1 is globally significant. The chosen variables allow for an explanation of over $90 \%$ of the behaviour of Brazilian exports.

An apparently surprising result is the one translated by the binary variables that capture the variation of Brazilian exports to other economic blocks (NAFTA and EU) regarding the fact that the country belongs to MERCOSUL. 
Table 2

Panel Data Results. OLS and Cross-section random effects. Dependent variable -EXPORT

\begin{tabular}{|l|c|c|}
\hline & Model 1-OLS & Model 2 - EA \\
\hline C & $41,159(1,973)^{* * *}$ & $40,854(7,04)^{* * *}$ \\
\hline LN(PIBBRASIL) & $0,559(0,109)^{* * *}$ & $0,555(0,074)^{* * *}$ \\
\hline LN(DISTBRASILIJ) & $0,900(0,021)^{* * *}$ & $0,908(0,059)^{* * *}$ \\
\hline DUNIAOECO=“NAFTA" & $-3,623(0,240)^{* * *}$ & $-3,582(0,916)^{* * *}$ \\
\hline DUNIAOECO=“UE" & $1,073(0,307)^{* * *}$ & $1,003(1,147)$ \\
\hline DIDIOMPT & $1,840(0,353)^{* * *}$ & $1,775(1,344)^{*} a$ \\
\hline DILHASPEQ & $0,107(0,187)$ & $0,121(0,717)$ \\
\hline DMAR & $-0,214(0,141)^{* a}$ & $0,189(0,516$ \\
\hline TCRISE & $1,309(0,085)^{* * *}$ & $1,296(0,320)^{* * *}$ \\
\hline & $-0,444(0,126)^{* * *}$ & $-0,443(0.075)^{* * *}$ \\
\hline Adjusted R & & 0,640 \\
\hline F-Statistic & 0,893 & 118,368 \\
\hline Observations & 549,438 & 594 \\
\hline
\end{tabular}

Notes: standard deviation in parenthesis; ${ }^{* *}$ significance $1 \%$; ${ }^{* *}$ significance $5 \%$; ${ }^{*}$ significance $10 \%$; *a not significant (although significance $10 \%$ unilateral)

Source: Authors' own elaboration.

The positive sign of the coefficients translates the higher attractiveness of the EU and NAFTA blocks in face of the MERCOSUL block. These results may be explained by the weak attractiveness of the countries belonging to the same economic block as Brazil, given the situation of crisis that is being lived by countries such as Argentina and Venezuela in the period in analysis. H1 is infirmed.

The estimated coefficients associated to the Brazilian GDP and the GDP of their partner countries present the expected sign. When Brazil's GDP varies $1 \%$, Brazilian exports vary in the same direction in $0,56 \%$; likewise, if the partner countries' GDP varies in $1 \%$, Brazilian exports vary in the same direction in $0,9 \%$.

The economic and productive dynamics of the importing and exporting countries are crucial variables to explain exports, confirming $\mathrm{H} 2$.

The estimated parameter for distance has the expected sign (if distance is over $1 \%$, then the exports will be lower in $3,6 \%$ ). This reflects the onus of increasing transportation costs with distance associated with international trade, confirming $\mathrm{H} 3$.

Regarding the remaining dummy variables, the results are as expected.

Having the sea as a border, and allowing cheaper access through maritime transportation, come as incentivizing factor for Brazilian exports (having sea suggests an increase of $130 \%$ of Brazilian exports in contrast with a country that does not have direct access to the sea), confirming H4.

Being a native Portuguese speaker and the condition of being a small island are two variables not statistically significant. Let us remember that these two binary variables are only pertinent for one country (Portugal) regarding the common language and two insular countries (Cyprus and Malta) - H5 and $\mathrm{H} 6$ are both rejected, being $\mathrm{H} 5$ in according theory.

The 2008 crisis has perverse effects on the Brazilian export dynamic. In fact, the post-crisis situation (2008 and following years), when compared to the period pre-crisis (years 2000 to 2007), correspond to a decrease in exports of $44,4 \%$, presenting Brazil as a country that is vulnerable to the international economic situation - H7 is confirmed.

The analysis of the results of model 2 allows us to confirm the signs obtained in model 1, showing stability of the estimates when using alternative estimation methods. 
Models 3 and 4 (similar models, like the case of models 1 and 2, only the change in estimation method was considered) assume as dependent variable the per capita exports (millions of USD per capita), and as independent variables the GDP per capita (USD per capita).

The reading of the estimates is in line with the two initial models. The coefficients' signs of the explanatory variables are stable, suggesting statistical trustworthiness in the advanced models.

Table 3

Panel Data Results. OLS and Cross-section random effects. Dependent variable - EXPORTPC

\begin{tabular}{|c|c|c|}
\hline & Model 3-OLS & Model 4 - EA \\
\hline $\mathrm{C}$ & $18,967(2,085) * * *$ & $18,265(7,117) * * *$ \\
\hline LN(PIBPCBRASIL) & $0,623(0,118) * * *$ & $0,569(0,082) * * *$ \\
\hline LN(PIBPCJ) & $0,857(0,039) * * *$ & $0,947(0,073) * * *$ \\
\hline LN(DISTBRASILIJ) & $-3,512(0,240) * * *$ & $-3,459(0,923) * * *$ \\
\hline DUNIAOECO="NAFTA" & $0,824(0,300) * * *$ & $0,638(1,129)$ \\
\hline DUNIAOECO="UE" & $1,772(0,356) * * *$ & $1,580(1,353)$ \\
\hline DIDIOMPT & $0,138(0,188)$ & $0,168(0,724)$ \\
\hline DILHASPEQ & $0,084(0,127)$ & $0,089(0,489)$ \\
\hline DMAR & $1,215(0,082) * * *$ & $1,199(0,316) * * *$ \\
\hline TCRISE & $-0,434(0,123) * * *$ & $-0,429(0,073) * * *$ \\
\hline Adjusted R ${ }^{2}$ & 0,726 & 0,575 \\
\hline F-Statistic & 175,551 & 90,117 \\
\hline Observations & 594 & 594 \\
\hline
\end{tabular}

Notes: standard deviation in parenthesis; ${ }^{* *}$ significance $1 \%$; ${ }^{* *}$ significance $5 \%$; ${ }^{*}$ significance $10 \%$; *a significance $10 \%$ unilateral

Source: Authors' own elaboration.

\section{CONCLUSIONS}

The application of gravitational models, making use of OLS estimators and cross-section random effects, show a robust analysis with globally significant models.

The economic and productive dynamics of the exporting and importing countries were confirmed as being explicative variables of exports. The fact that a country belongs to an economic block is not sufficient to explain the dynamic of the intra-block exports (the case of Brazil). Higher maritime transports access facilitates international trade. Transportation costs as measured by distance inhibit international transactions. The economic and financial crisis of 2008 has severely impacted the export dynamics of countries like Brazil.

However, the specificities of the gravitational model applied to heterogeneous economics, in particular developing economics, is still a matter to reflect on. In the Brazilian case, including variables like exchange rate volatility, relative international prices, matters of transparency and freedom of doing business, on one hand; considering the finer analysis of exports, revealing the different exporting sectors, complementing the aggregated analysis, may, as well as broadening the sample to countries that capture Brazilian exports (namely the inclusion of China), on the other hand, should be considered in following studies. 


\section{REFERENCES}

AITKEN, N.D. (1973). "The Effects of the EEC and EFTA on European Trade: A Temporal Cross-Section Analysis", in American Economic Review ,5, pp.881-892

ANDERSON, J.E. (1979). "A Theoretical Foundation for the Gravity Equations", American Economic Review, 69, pp.106-116

ANDERSON, J.E. AND van WINCOOP, E.(2003). "Gravity with Gravitas: A Solution to the Border Puzzle".in American Economic Review, 93(1), pp. 170-192

ANDERSON, J.E. AND van WINCOOP, E.(2004). "Trade Costs." In Journal of Economic Literature, 42 (3), pp.691751

AREVALO,J.L.S., ANDRADE,Á.M.F. AND SILVA,G.A.B. (2017) . "Uma Nota Sobre Modelos Gravitacionais Aplicados à Exportação de Café de Brasil, Colômbia e Peru”. In Revista Brasileira de Economia , 70 (3), pp. 271-280

AZEVEDO, A.F.Z. (2004). "O efeito do Mercosul sobre o comercio: uma análise com o modelo gravitacional", in Pesquisa e Planejamento Econômico, 34, pp. 307-339

BAIER, S.L. AND BERGSTRAND, J.H. (2014). "Approximating general equilibrium impacts of trade liberalizations using the gravity equation: Applications to NAFTA and the European Economic Area". In Bergeijk, P.A.G.van and Brakman, S. (ed.): The Gravity Model in International Trade (pp.88-134). Cambridge: Cambridge University Press

BERGEIJK, P.A.G.van and BRAKMAN, S. (2014). "Introduction: The comeback of the gravity model". In Bergeijk, P.A.G.van and Brakman, S. (ed.): The Gravity Model in International Trade (pp. 1-26). Cambridge: Cambridge University Press

BERGSTRAND, J. (1985). "The Gravity Equation in International Trade: Some Microeconomic Foundations and Empirical Evidence", in The Review of Economics and Statistics, 67(3), pp. 474-81

CEPII - (s.d) Centre d'Études Prospectives et d'Informations Internationales, in www.cepii.fr/

COLIN, A. (2015). Images Économiques du Monde 2016, Paris: Dunod Editeur

DEARDORFF, A. (1998). "Determinants of Bilateral Trade: Does Gravity Work in a Neoclassical Word?", in Franked, J. (ed.), The Regionalization of the World Economy, (pp.7-28). Chicago: University of Chicago Press

EATON, J. AND KORTUM, S. (2002). "Technology, Geography, and Trade", Econometrica, 70 (5), pp. 1741-1779

EGGER, P. AND PFAFFERMAYR,M. (2004). "The impact of bilateral investment treaties on foreign direct investment", in Journal of Comparative Economics, 32(4), pp.788-804

FREENSTRA, R.C. (2004). Advanced International Trade, Princeton: Princeton University Press

GRĀF, C.O AND AZEVEDO, A.F.Z.(2013). "Comércio bilateral entre países membros do MERCOSUL: Uma visão do bloco através do modelo gravitacional". In Economia Aplicada, 17 (1), pp. 135-158

HELLIWELL, J.F. (1997). "National Borders, Trade and Migrations", in Pacific Economic Review, 2(3), pp. 165-185

HELPMAN, E. (1987). "Imperfect competition and international trade: Evidence from fourteen industrial countries", in Journal of the Japanese and International Economies, 1(1), pp.62-81

HELPMAN,E. AND KRUGMAN, P. (1985). Market Structure and Foreign Trade: Increasing Returns, Imperfect Competition and the International Economy .Cambridge, MA

IMF - International Monetary Fund. (2017). International Monetary Fund. Available at www.imf.org/external/pubs/ft/weo/2017/01/weodata/index.aspx

LINNEMANN, H. (1966). An Econometric Study of International Trade Flows, Amesterdam: North-Holand

McCALLUM, J. (1995). "National Borders Matter: Canada-US Regional Trade Patterns", in American Economic Review, 85(3), pp. 615-623

MDIC - Ministério de Desenvolvimento, Indústria e Comércio Exterior (2017) - Sistema AliceWeb. (s.d.). Acessed on the 9th March 2017. Available at aliceweb.mdic.gov.br/

MDIC - Ministério de Desenvolvimento, Indústria e Comércio Exterior (2017 b). Balança comercial brasileira: Acumulado do ano. Accessed on the 5th May 2017. Available at www.mdic.gov.br/index.php/comercioexterior/estatisticas-de-comercio-exterior/balanca-comercial-brasileira-acumulado-do-ano

PAPAZOGLOU, C. (2007). "Greece's Potencial Trade Flows: A Gravidity Model Approach", in International Advances in Economic Research, Springer: International Atlantic Economic Society, 13 (4), pp. 403-414

PIANI, G. AND KUME, H. (2010). "Fluxos Bilaterais de Comércio e Blocos Regionais: uma aplicação do Modelo Gravitacional", Rio de Janeiro, http://repositorio.ipea.gov.br/bitstream/11058/2279/1/TD_749.pdf (Last acess: May 2018)

PöYHöNEN, P. (1963). "A Tentative Model for the Volume of Trade between Countries", in Weltwirstschaftliches Archiv, 90, pp. 93-99

SÁ PORTO, P.C.(2002). "Mercosul and Regional Development in Brazil: A Gravity Model Approach", in Estudos de Economia, 32(1), pp.125-153

SAPIR, A. (1981)."Trade Benefits under the EEC Generalized System of Preferences", in European Economic Review ,15, pp.339-355

TARTAS, R.L. (2016). "Potencial de Comércio Brasileiro com seus Principais Parceiros: Uma Análise com o Modelo Gravitacional. UNISINOS. São Leopoldo. RS, http://www.repositorio.jesuita.org.br/handle/UNISINOS/5769 (Last acess: May 2018)

TINBERGEN, J. (1962). Shapping the World Economy: Suggestions for an International Economic Policy, New York:Twentieth Century Fund

UN Comtrade | International Trade Statistics Database. (s.d.). http://WWW.comtrade.un.org/. (Last acess:

September 2017) 